\title{
EFFECT OF DIFFERENT DOSES OF NUTRIENTS ON CHANGES OF SOIL ORGANIC MATTER IN RENDZIC LEPTOSOL
}

\author{
VLADIMÍR ŠIMANSKÝ, ERIKA TOBIAŠOVÁ
}

Slovak University of Agriculture in Nitra

ŠIMANSKÝ, V. - TOBIAŠOVÁ, E.: Effect of different doses of nutrients on changes of soil organic matter in Rendzic Leptosol. Agriculture (Pol'nohospodárstvo), vol. 58, 2012, no. 4, pp. 131-137.

The effect of different doses of NPK fertilizer on the changes in quantity and quality of soil organic matter (SOM) in Rendzic Leptosol was evaluated. Soil samples were taken from three treatments of different fertilization: (1) control - without fertilization, (2) NPK 1 - doses of NPK fertilizer in $1^{\text {st }}$ degree intensity for vine, and (3) NPK 3 - doses of NPK fertilizer in $3^{\text {rd }}$ degree intensity for vine in the vineyard. Soil samples were collected in years 2008-2011 during the spring. The higher dose of NPK fertilizer ( $3^{\text {rd }}$ degree intensity of vineyards fertilization) was responsible for the higher content of labile carbon

Key words: fertilization, soil organic matter, vineyard

Soil organic matter (SOM) is an essential component with key multifunctional roles in soil quality and is related to many physical and biological properties of soil (Smith et al. 1999). SOM is influenced by several factors: for example climate, clay content and mineralogy, soil management practices, which affect the processes of organic matter transformation and evolution in soil (Oades 1995; Šimanský et al. 2009; Polláková \& Konôpková 2012). Positive changes in agricultural management, including application of organic fertilizers, crop rotations, and protection of tillage (Jarecki et al. 2005; Šimanský \& Tobiašová 2010), can increase soil organic matter; however, negative management can decrease its content.

Many reports have shown that long-term addition of organic matter improves crop yield, water holding capacity, porosity and water-stable aggregation, and decreases bulk density and surface crusting (Edwards (by $21 \%$ in $0-0.3 \mathrm{~m}$ and by $11 \%$ as average of the two depths $0-0.3 \mathrm{~m}$ and $0.3-0.6 \mathrm{~m})$. However, by application of a higher dose of NPK $(1.39 \%)$ in comparison to no fertilizer treatment $(1.35 \%)$ or NPK $1(1.35 \%)$ the tendency of total organic carbon content increase and hot-water soluble carbon decrease were determined. Fertilization had a negative effect on SOM stability. Intensity of fertilization affected the changes in quantity and quality of SOM; therefore it is very important to pay attention to the quantity and quality of organic matter in productive vineyards.
\& Lofty 1982; Schjønning et al. 1994). Nitrogen fertilization can significantly increase crop residue inputs to the soil, resulting in increases in soil organic matter. Halvorson et al. (1999) presented, that a good $\mathrm{N}$ fertility program helps sequestering atmospheric $\mathrm{CO}_{2}$ into soil organic carbon by increased plant growth and subsequently, the return of organic $\mathrm{C}$ to the soil for storage as soil organic matter in a no-till system. Application of N, NP, NPK and NPK + lime caused a significant decline in soil organic C (Manna et al. 2007).

Leptosols are very shallow soils over continuous rock and soils that are extremely gravelly and/or stony. Leptosols are azonal soils particularly common in mountainous regions (WRB 2006). Leptosols are the most extensive on the Earth. In Slovakia, Leptosols include $4.7 \%$ of agricultural land. The average content of SOM is $3.5 \%$ (Bielek et al. 1998). There is little knowledge about the changes in soil organic matter of

doc. Ing. Vladimír Šimanský, Ph.D., doc. Ing. Erika Tobiašová, Ph.D., Department of Soil Science, Faculty of Agrobiology and Food Resources - Slovak University of Agriculture in Nitra, 94976 Nitra, Tr. A. Hlinku 2. E-mail: Vladimir.Simansky@uniag.sk; Erika.Tobiasova@uniag.sk 
Rendzic Leptosols due to different soil management or different doses of fertilizers, respectively. This knowledge is important for assessing the potential to form optimal soil properties and carbon sequestration in Rendzic Leptosols.

The objective of this study was to evaluate the effect of different doses of NPK fertilizer on the changes in quantity and quality of soil organic matter in Rendzic Leptosol.

\section{MATERIAL AND METHODS}

The experiment with different doses of NPK fertilizer in the vineyard was conducted (from 2006 to present day) on a Rendzic Leptosol, developed on limestone and dolomite in the locality of NitraDražovce (48 $\left.21^{\prime} 6.16^{\prime \prime} \mathrm{N} ; 18^{\circ} 3^{\prime} 37.33^{\prime \prime} \mathrm{e}\right)$. Some characteristics of the soil are given in Table 1. In the soil profile, rock fragments were observed (to a depth

$\mathrm{T}$ a $\mathrm{b} 1 \mathrm{e} 1$

Chemical properties of soil $(0.0-0.6 \mathrm{~m})$

\begin{tabular}{|l|c|c|}
\hline \multirow{2}{*}{ Chemical properties } & \multicolumn{2}{|c|}{ Depth } \\
\cline { 2 - 3 } & $0.0-0.3 \mathrm{~m}$ & $0.3-0.6 \mathrm{~m}$ \\
\hline $\mathrm{pH}$ & $7.18 \pm 0.08$ & $7.42 \pm 0.06$ \\
Organic carbon $[\mathrm{g} / \mathrm{kg}]$ & $17.00 \pm 1.60$ & $9.80 \pm 2.60$ \\
Base saturation $[\%]$ & $99.30 \pm 0.01$ & $99.60 \pm 0.02$ \\
Total nitrogen $[\mathrm{mg} / \mathrm{kg}]$ & $1,867 \pm 103$ & $1,666 \pm 284$ \\
Available phosphorus $[\mathrm{mg} / \mathrm{kg}]$ & $99 \pm 8$ & $53 \pm 4$ \\
Available potassium $[\mathrm{mg} / \mathrm{kg}]$ & $262 \pm 15$ & $114 \pm 19$ \\
\hline
\end{tabular}

\pm Standard deviation, available P and K - determined by Mehlich III (Mehlich 1984), total nitrogen content was determined according Kjeldahl

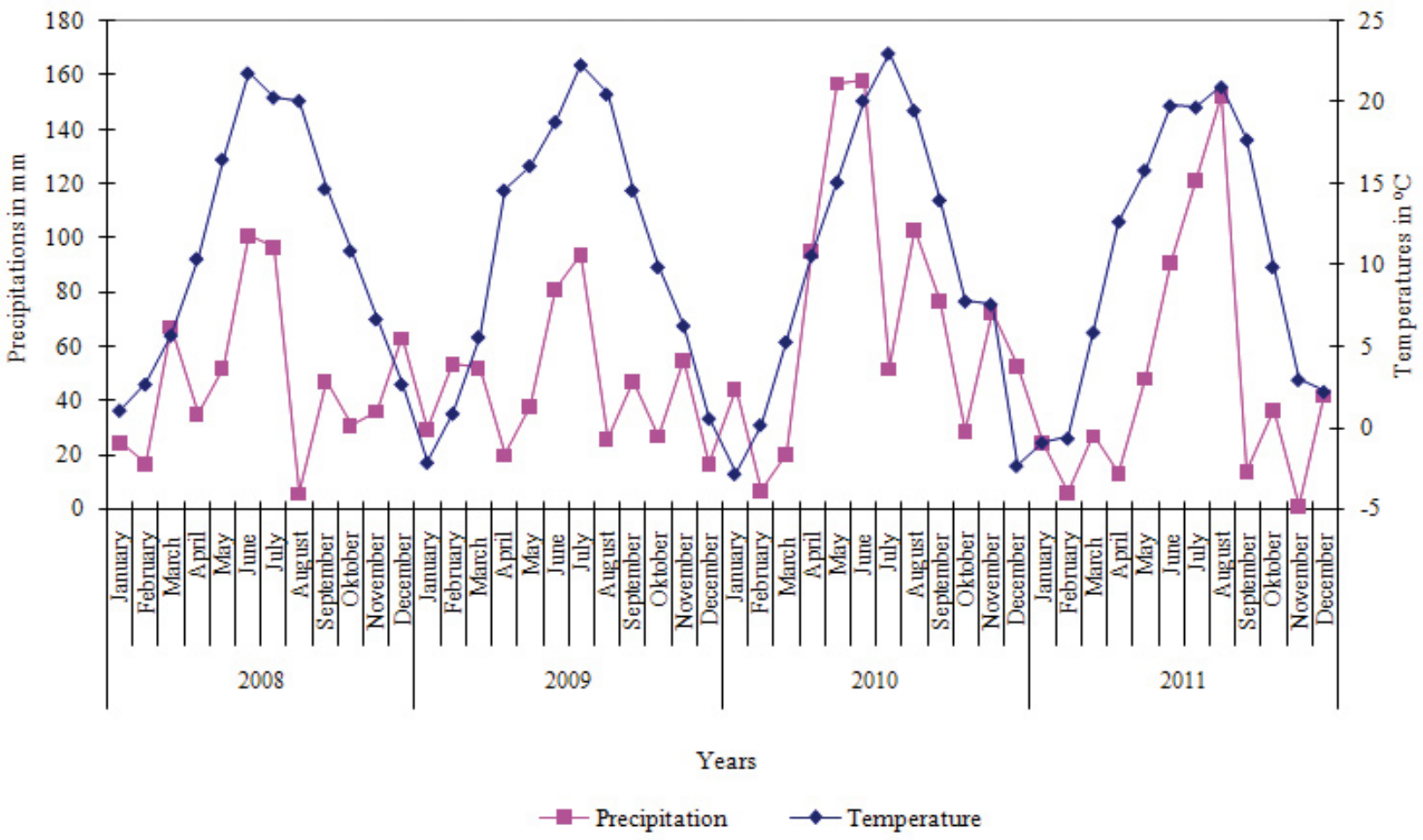

Figure 1. Climatical characteristics (precipitations, temperatures) during years 2008-2011 
$0.3 \mathrm{~m}=8 \%$ ). The particle-size distribution is $569 \mathrm{~g} / \mathrm{kg}$ of sand, $330 \mathrm{~g} / \mathrm{kg}$ of silt and $101 \mathrm{~g} / \mathrm{kg}$ of clay (determined by pipette method as is mentioned in Fiala et al. 1999). Long-term annual mean temperature and precipitations at the area are $10^{\circ} \mathrm{C}$ and $550 \mathrm{~mm}$, respectively (Špánik et al. 2002). The weather conditions during the years 2008-2011 are in Figure 1.

Before planting, the soil was rippered to the depth of $0.4 \mathrm{~m}$ and then ploughed to a depth of $0.3 \mathrm{~m}$. Grapevines (Vitis vinifera L. cv. Chardonnay) were planted in 2000 at a density of 0.33 stocks $/ \mathrm{m}^{2}(3 \times 1 \mathrm{~m})$. They were trained using a Rheinish-Hessian system. A variety of grasses was used in the inter-rows of the grapevines; these were sown in 2003. During vegetation season of grapevine the biomass of grasses was cut down four-five times per year.

Three types of fertilization were studied: (1) without fertilization $(\mathrm{Co})$ - control treatment - sown grass in the rows and between vine rows, (2) NPK 1 - doses of NPK fertilizer in $1^{\text {st }}$ degree intensity for vineyards (Fecenko \& Ložek 2000); it means $80 \mathrm{~N} \mathrm{~kg} / \mathrm{ha}, 35$ $\mathrm{P} \mathrm{kg} / \mathrm{ha}$ and $135 \mathrm{~K} \mathrm{~kg} / \mathrm{ha}$. The dose of fertilizer was divided: $1 / 2$ applied into the soil in spring (bud burst) and $1 / 2$ at flowering. Grass was sown in and between the vine rows. (3) NPK 3 - doses of NPK fertilizer in $3^{\text {rd }}$ degree intensity for vineyards (Fecenko \& Ložek 2000); it means $120 \mathrm{~N} \mathrm{~kg} / \mathrm{ha}, 55 \mathrm{P} \mathrm{kg} / \mathrm{ha}$ and 195 $\mathrm{K} \mathrm{kg} / \mathrm{ha}$. The dose of nutrients was divided: $2 / 3$ applied into the soil in spring (bud burst) and 1/3 at flowering. Grass was sown in and between the vine rows.
Soil samples were collected in spring 2008-2011 from two depths $(0.0-0.3$ and $0.3-0.6 \mathrm{~m})$ from six blocks of individual treatments per vineyard. Plant residues were carefully removed from the soil samples. The sub-samples of each treatment were mixed to average samples, dried at laboratory temperature and ground before analysis. We determined the total organic carbon content $\left(\mathrm{C}_{\text {org }}\right)$ according to Tyurin (Dziadowiec \& Gonet 1999), the fraction composition of humus substances according to Belchikova and Kononova (Dziadowiec \& Gonet 1999) and optical parameters of humus substances and humic acids within the soil samples. The labile carbon content $\left(\mathrm{C}_{\mathrm{L}}\right)$ (Loginow et al. $1987)$ and hot-water soluble carbon $\left(\mathrm{C}_{\mathrm{HWD}}\right)$ (Körschens 2002) were determined as well.

Statistical analyses were performed by using Statgraphics Plus. To test the significant differences between the investigated treatments, an analysis of variance was performed. Treatment differences were considered significant at $P$ values $\leq 0.05$ by the Tukey test.

\section{RESULTS AND DISCUSSION}

Fertilization had no significant influence on the total organic carbon content $\left(\mathrm{C}_{\text {org }}\right)$ in the soil at two sampling depths $(0.0-0.3$ and $0.3-0.6 \mathrm{~m})$, which confirmed the results of Haynes (2005). This could be because a major part of the $\mathrm{C}_{\text {org }}$ is formed of the stable

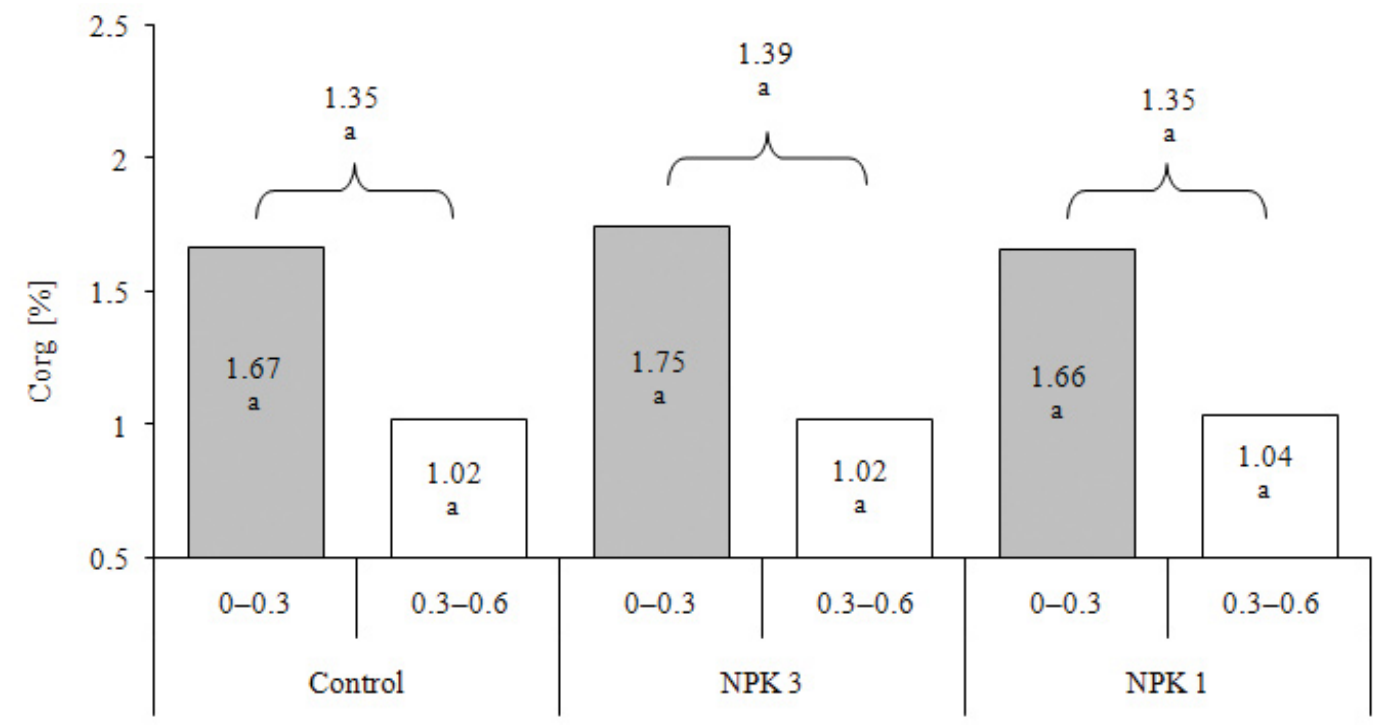

Figure 2. Contents of total organic carbon

Different letters between columns and treatments $(\mathrm{a}, \mathrm{b})$ indicate significant difference at $P \leq 0.05$ according to Tukey test 
fraction of organic matter and it has been turned-over thousands of times over the years. However, by applying a higher dose of NPK ( $3^{\text {rd }}$ degree intensity of vineyards fertilization) in comparison to no fertilizer treatment or NPK 1, the tendency of $\mathrm{C}_{\text {org }}$ increase was determined. The average values were $1.38 \%, 1.35 \%$ for NPK 3 and NPK 1, respectively as compared to $1.34 \%$ under Co (control, no fertilizer). Fertilizers applied to soil can result in a higher production of biomass, which leads to increases in SOM content (Neff et al. 2002). Among sampling depths, the top one (0.0-0.3 $\mathrm{m})$ had significantly higher $\mathrm{C}_{\text {org }}$ than the lower depth (0.3-0.6 m), particularly under NPK 3 (Figure 2). The labile fractions have a much shorter turnover time and thus are affected by management-induced changes in organic matter inputs or losses, much more rapidly.

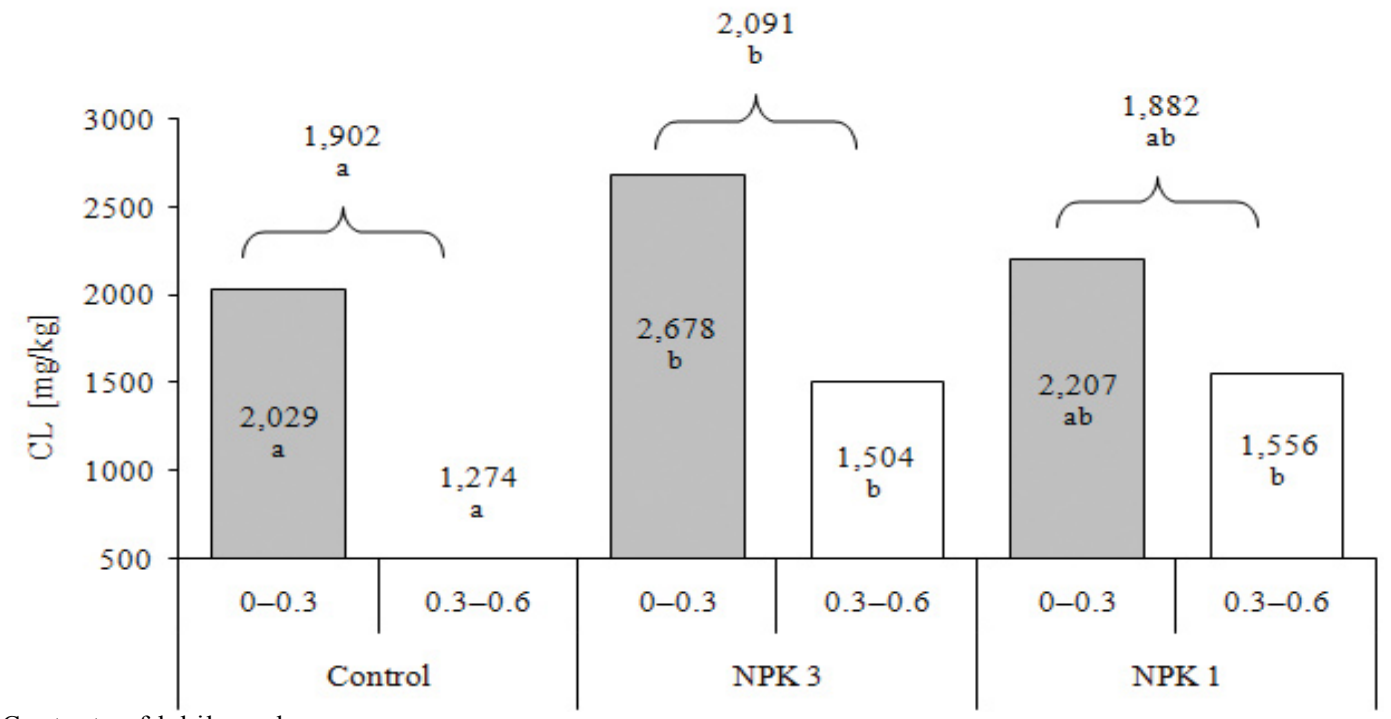

Figure 3. Contents of labile carbon

Different letters between columns and treatments $(\mathrm{a}, \mathrm{b})$ indicate significant difference at $P \leq 0.05$ according to Tukey test

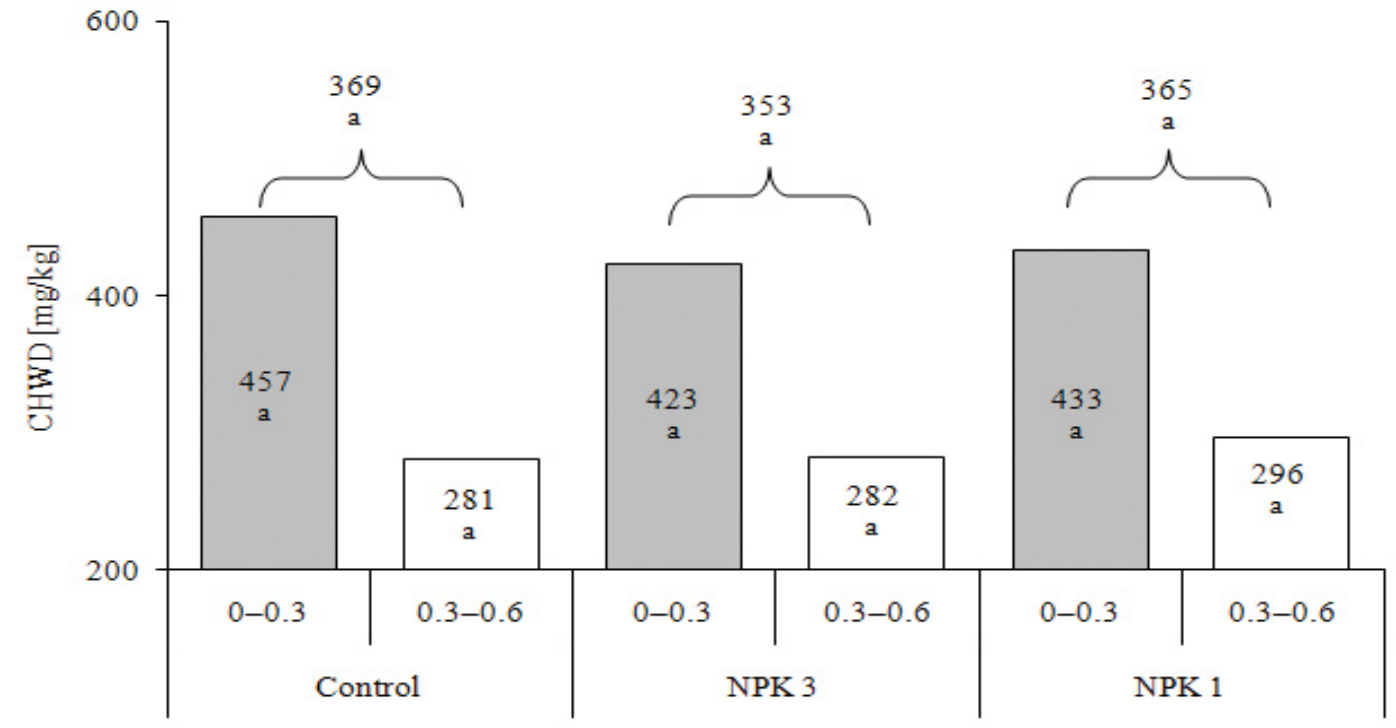

Figure 4. Contents of hot-water soluble carbon

Different letters between columns and treatments $(\mathrm{a}, \mathrm{b})$ indicate significant difference at $P \leq 0.05$ according to Tukey test 
The labile carbon content $\left(\mathrm{C}_{\mathrm{L}}\right)$ was significantly af- higher content of root exudates. The results published fected by different fertilization (Figure 3). Soil under NPK 3 showed significantly higher $\mathrm{C}_{\mathrm{L}}$ content as compared to other two fertilization treatments (NPK 1 and Co) at both depths. Results show that the contents of $\mathrm{C}_{\mathrm{L}}$ increased significantly with higher dose of NPK. In case of NPK 3 treatment, a higher content of nutrients was the reason of greater root biomass with a by Šimanský (2011) confirmed this fact. Hot-water soluble carbon content in soil (carbon of microbial origin) $\left(\mathrm{C}_{\mathrm{HWD}}\right)$ varied from 204 to $618 \mathrm{mg} / \mathrm{kg}$ and its contents depended on soil depth; however, the fertilization did not have statistically significant effect on $\mathrm{C}_{\mathrm{HWD}}$ (Figure 4). In fertilization treatments, the $\mathrm{C}_{\mathrm{HWD}}$ can be arranged in the following order: Co $>$ NPK $1>$

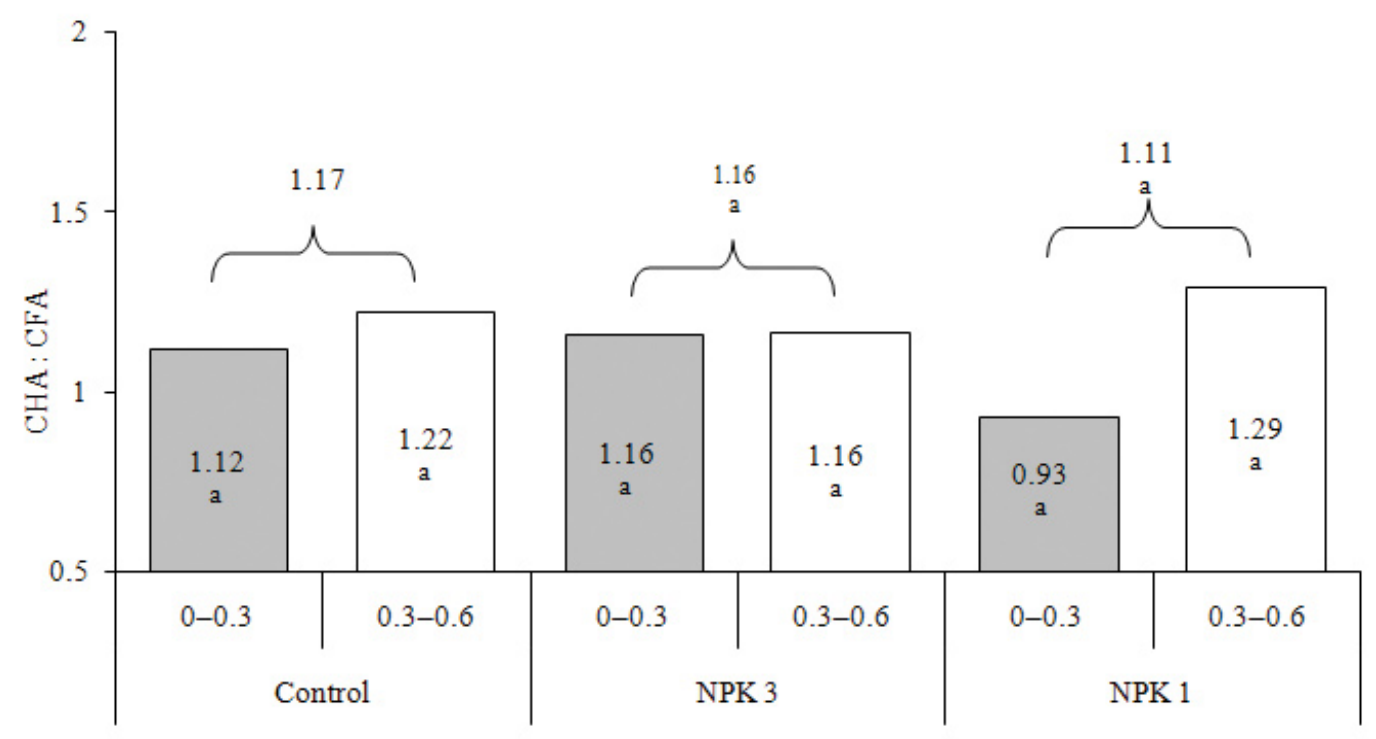

Figure 5. $\mathrm{C}_{\mathrm{HA}}: \mathrm{C}_{\mathrm{FA}}$ ratios

Different letters between columns and treatments $(\mathrm{a}, \mathrm{b})$ indicate significant difference at $P \leq 0.05$ according to Tukey test

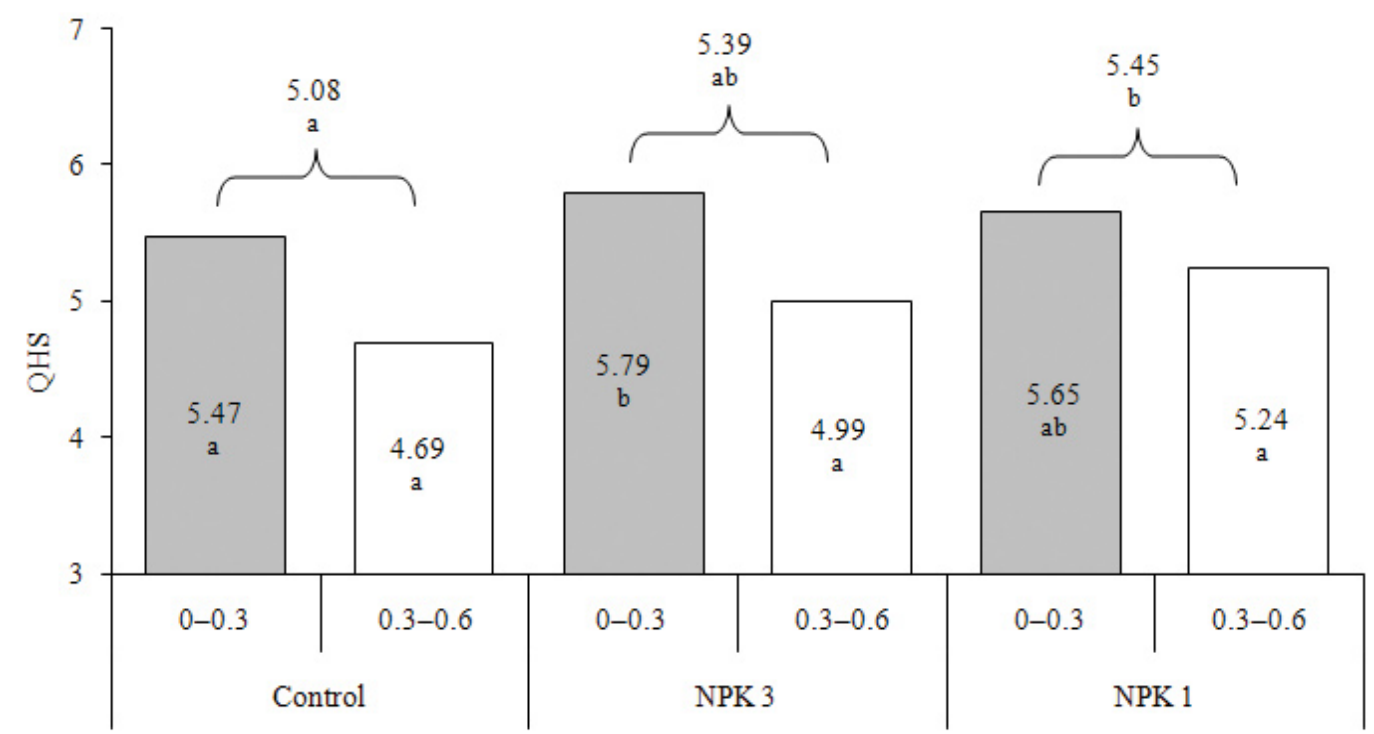

Figure 6. Color quotient of humic substances

Different letters between columns and treatments $(\mathrm{a}, \mathrm{b})$ indicate significant difference at $P \leq 0.05$ according to Tukey test 
NPK 3. Due to the application of a higher dose of NPK ( $3^{\text {rd }}$ degree intensity of vineyards fertilization) in comparison to control or NPK 1 treatment, the tendency of $\mathrm{C}_{\mathrm{HWD}}$ decrease was determined. The main reason of $\mathrm{C}_{\mathrm{HWD}}$ decrease can be a higher concentration of soil solution due to the applied fertilizer, which affects the microbial activity negatively.

We also evaluated the quality and stability of the soil organic matter with regard to the fertilization in the vineyard. As can be seen in Figure 5, during fertilization (NPK 3 and NPK 1) treatment the average values of the $\mathrm{C}_{\mathrm{HA}}: \mathrm{C}_{\mathrm{FA}}$ ratio (in both depths) were narrower (1.16 and 1.11, respectively); however, in Co, it was the widest (1.17). During the period 2008-2011, the obtained results were not statistically confirmed; this means that there has been only negative trend in the quality of soil organic matter due to the fertilizer in the vineyard. Zalba and Quiroga (1999) determined a higher content of fulvic acid due to fertilization that affected the narrowing ratio of $\mathrm{C}_{\mathrm{HA}}: \mathrm{C}_{\mathrm{FA}}$; this corresponds to our results (Figure 5). Application of fertilization to the soil can increase mineralization (Jagadamma et al. 2007) and this negatively affects the stability of organic substances and overall quality of SOM (Zalba \& Quiroga 1999). The average values of color quotient of humic substances $\left(\mathrm{Q}_{\mathrm{HS}}\right)$ and humic acids $\left(\mathrm{Q}_{\mathrm{HA}}\right)$ were the most favourable in the control treatment. Fertilization had a negative effect on SOM stability (Figures
6 and 7). The average values of $\mathrm{Q}_{\mathrm{HS}}$ and $\mathrm{Q}_{\mathrm{HA}}$ at both depths were higher by $7 \%$ and by $6 \%$ under NPK 3 and higher by $6 \%$ and $6 \%$, respectively under NPK 1 in comparison to Co.

\section{CONCLUSION}

The results of this study demonstrated that fertilizer applied to the soil statistically significantly increased the labile carbon content. The higher dose of NPK fertilizer ( $3^{\text {rd }}$ degree intensity of vineyards fertilization) was responsible for the higher the content of labile carbon. However, by applying a higher dose of NPK in comparison to no fertilizer treatment or NPK 1 the tendency of total organic carbon content increase and hot-water soluble carbon decrease were determined. Fertilization had a negative effect on SOM stability.

Intensity of fertilization affected the changes in quantity and quality of SOM; therefore, it is very important to pay attention to the quantity and quality of organic matter in productive vineyards. In conclusion, the parameters like labile carbon content and color quotients of humic substances or humic acids reacted to the changes of SOM more sensitively due to fertilizer application during the years 2008-2011. This means that they can be used as indicators of SOM degradation in relation to fertilization of soils.

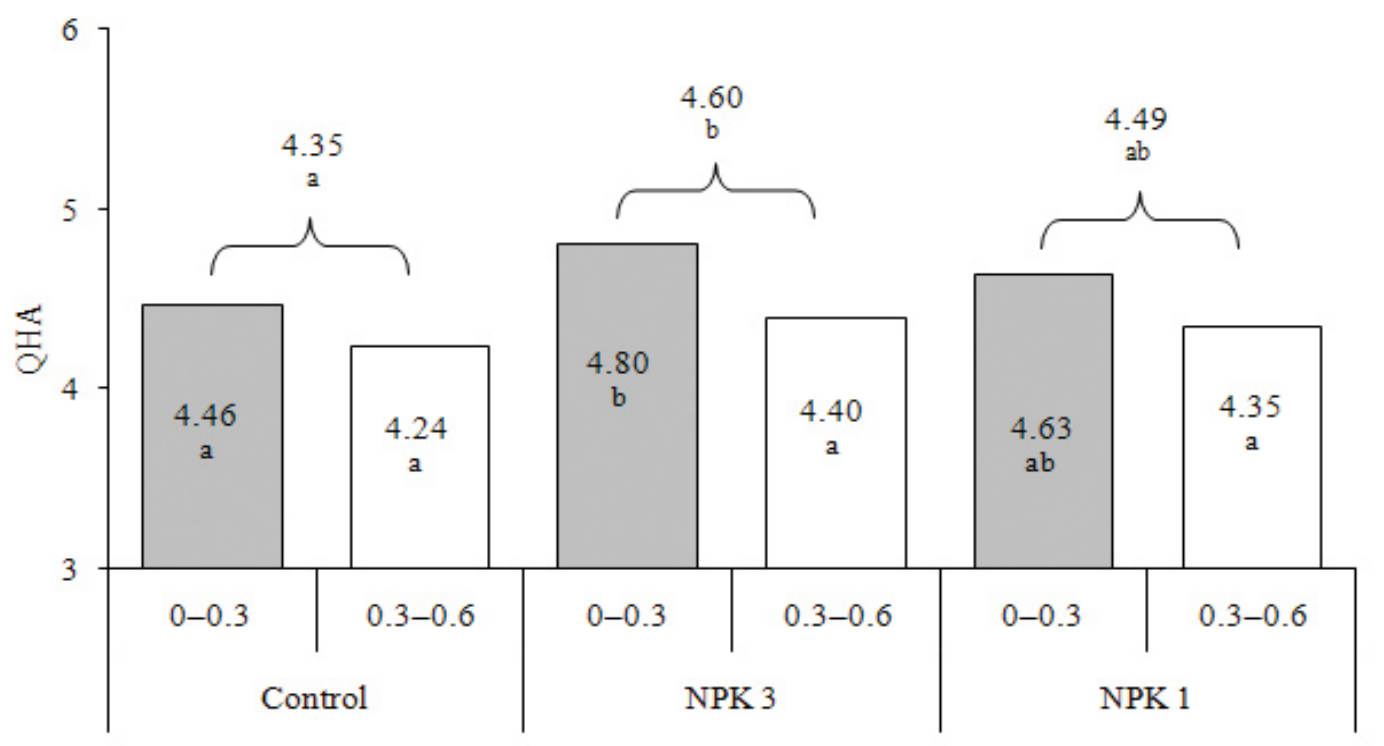

Figure 7. Color quotient of humic acids

Different letters between columns and treatments $(\mathrm{a}, \mathrm{b})$ indicate significant difference at $P \leq 0.05$ according to Tukey test 
Acknowledgments. The project was supported by the Scientific Grant Agency of the Ministry of Education of the Slovak Republic and the Slovak Academy of Sciences (no. 1/0300/11).

\section{REFERENCE}

BIELEK, P. - ŠURINA, B. - ILAVSKÁ, B. - VILČEK, J. 1998. Naše pôdy [Our soils]. Bratislava : VÚPÚ, 1998. 82 p. ISBN 80-85361-42-6

DZIADOWIEC, H. - GONET, S.S. 1999. Przewodnik metodyczny do badań materii organicznej gleb [Methodical guide-book for soil organic matter studies]. Warszawa : Prace Komisji Nauk PTG, no. 120, 1999, pp. 64.

EDWARDS, C.A. - LOFTY, J.R. 1982. Nitrogenous fertilizers and earthworms populations in agricultural soils. In Soil Biology and Biochemistry, vol. 14, 1982, no. 5, pp. 515-521.

FECENKO, J. - LOŽEK, O. 2000. Výźiva a hnojenie pol'ných plodin [Nutrition and Fertilization of Field Crops]. Nitra : SPU, 2000. 452 p. ISBN 80-7137-777-5

FIALA, K. - KOBZA, J. - MATÚŠKOVÁ, L. - BREČKOVÁ, V. - MAKOVNÍKOVÁ, J. - BARANČÍKOVÁ, G. BÚRIK, V. - LITAVEC, T. - HOUŠKOVÁ, B. - CHROMANIČOVÁ, A. - VÁRADIOVÁ, D. - PECHOVÁ, B. 1999. Valid methods of soil analyses. Partial monitoring system - Soil. Bratislava : SSCRI, 1999. 142 p. ISBN 80-85361-55-8

HALVORSON, A.D. - REULE, C.A. - FOLLETT, R.F. 1999. Nitrogen fertilization effects on soil carbon and nitrogen in a dryland cropping system soil. In Soil Science Society of America Journal, vol. 63, 1999, no. 4, pp. 912-917. DOI: 10.2136/sssaj 1999.634912x

HAYNES, R.J. 2005. Labile organic matter fractions as central components of the quality of agricultural soils: an overview. In Advances in Agronomy, vol. 85, 2005, pp. 221-268. ISBN 978-0-12-000783-7

IUSS Working Group WRB. 2006. World reference base for soil resources. 2006. World Soil Resources Reports No. 103, Roma : FAO, pp. 145.

JAGADAMMA, S. - LAL, R. - HOEFT, R.G. - NAFZIGER, E.D. - ADEE, E.A. 2007. Nitrogen fertilization and cropping systems effects on soil organic carbon and total nitrogen pools under chisel-plow tillage in Illinois. In Soil and Tillage Research, vol. 95, 2007, no. 1-2, pp. 348-356. DOI: 10.1016/j.still.2007.02.006

JARECKI, M.K. - LAL, R. - JAMES, R. 2005. Crop management effects on soil carbon sequestration on selected farmers' fields in northeastern Ohio. In Soil and Tillage Research, vol. 81, 2005, pp. 265-276. DOI:10.1016/ j.still.2004.09.013

KÖRSCHENS, M. 2002. Importance of soil organic matter for biomass production and environment a review. In Arckerbaulicher Massnahmen auf die Bodenfruchtbarkeit, vol. 48, 2002, pp. 89-94.

LOGINOV, W. - WISNIEWSKI, W. - GONET, S.S. - CIESCINSKA, B. 1987. Fractionation of organic carbon ba- sed on susceptibility to oxidation. In Polish Journal of Soil Science, vol. 20, 1987, pp. 47-52.

MANNA, M.C. - SWARUP, A. - WANJARI, R.H. - MISHRA, B. - SHAHI, D.K. 2007. Long-term fertilization, manure and liming effects on soil organic matter and crop yields. In Soil and Tillage Research, vol. 94, 2007, no. 2, pp. 397-409. DOI: 10.1016/j.still.2006.08.013

MEHLICH, A. 1984. Mehlich 3 soil tests extractant: A modification of Mehlich 2 extractant. In Communication in Soil Science and Plant Analysis, vol. 15, 1984, no. 12, pp. 1409-1416. DOI:10.1080/00103628409367568

NEFF, J.C. - TOWNSEND, A.R. - GLEIXNER, G. 2002. Variable effects of nitrogen additions on the stability and turnover of soil carbon. In Nature, vol. 419, 2002, pp. 915-917.

POLLÁKOVÁ, N. - KONÔPKOVÁ, J. 2012. Vlastnosti pôdy pod vybranými domácimi a introdukovanými druhmi drevín v Arboréte Mlyñany [Soil properties under selected indigenous and introduced tree species in Arboretum Mlyňany]. Nitra : SPU, 2012. pp. 88. ISBN 978-80-5520831-2

OADES, J.M. 1995. An overview of processes affecting the cycling of organic carbon in soils, In ZEPP, R.G. - SONNTAG, CH. (Eds.).: Role of Non Living Organic Matter in the Earth's Carbon Cycle. England : Wiley \& Sons Ltd., 1995. ISBN 0-471-95463-2, pp. 55-94.

SCHJØNNING, P. - CHRISTENSEN, B.T. - CARSTENSEN, B. 1994. Physical and chemical properties of a sandy loam receiving animal manure, mineral fertilizer or no fertilizer for 90 years. In European Journal of Soil Science, vol. 45, 1994, no. 3, pp. 257-268. DOI: 10.1111/ j.1365-2389.1994.tb00508.x

SMITH, O.H. - PETERSEN, G.W. - NEEDELMAN, B.A. 1999. Environmental indicators of agroecosystems. In Advances in Agronomy, vol. 69, 1999, pp. 75-97.

ŠIMANSKÝ, V. 2011. Rozdiely v stabilite štruktúry pôdy v dôsledku jej hnojenia [Differences aggregate stability of soil due to various fertilization]. In Agrochémia, vol. 50, 2011, no. 3, pp. 16-19.

ŠIMANSKÝ, V. - TOBIAŠOVÁ, E. - JANKOWSKI, M. MARKIEWICZ, M. 2009. Particle-size distribution and land-use effects on quantity and quality of soil organic matter in different soils of Slovakia and Poland. In $\mathrm{Ag}$ riculture (Pol'nohospodárstvo), vol. 55, 2009, no. 3, pp. $125-132$.

ŠIMANSKÝ, V. - TOBIAŠOVÁ, E. 2010. Impact of tillage, fertilization and previous crop on chemical properties of Luvisol under barley farming system. In Journal of Central European Agriculture, vol. 11, 2010, no. 3, pp. 245-253.

ŠPÁNIK, R. - REPA, Š. - ŠIŠKA, B. 2002. Agroklimatické a fenologické pomery Nitry [Agro-climatic and phenological conditions of Nitra]. Nitra : SPU, 2002. 39 p. ISBN 80-7137-987-5

ZALBA, P. - QUIROGA, A.R. 1999. Fulvic acid carbon as a diagnostic feature for agricultural soil evaluation. In Soil Science, vol. 164, 1999, no. 1, pp. 57-61.

Received: September $11^{\text {th }}, 2012$ 